\title{
PERANAN KOMUNIKASI PADA PROSES SUKSESI DI PERUSAHAAN KELUARGA STUDI PADA PT. CATUR PUTRA HARMONIS
}

\author{
1) Monika Teguh, ${ }^{2)}$ Andrew Wijaya \\ ${ }^{1,2)}$ Program Studi Ilmu Komunikasi dan Bisnis Media, Universitas Ciputra Surabaya \\ ${ }^{1,2)}$ CitraLand CBD Boulevard, Made, Kec. Sambikerep, Kota Surabaya, Jawa Timur 60219- \\ Indonesia \\ E-mail : Monika.teguh@ciputra.ac.id
}

\begin{abstract}
ABSTRAK
Indonesia merupakan salah satu negara yang perekonomiannya dipengaruhi oleh perusahaan keluarga. Sebuah studi menyebutkan bahwa 25\% Produk Domestik Bruto (PDB) Indonesia dipengaruhi oleh perusahaan keluarga. Tingginya pengaruh serta peranan perusahaan keluarga di Indonesia membuat keberlangsungan dan pertumbuhan perusahaan keluarga menjadi sangat penting untuk diperhatikan dengan seksama. Namun perusahaan keluarga memiliki masalah khas yaitu suksesi perusahaan. Seringkali perusahaan keluarga hanya mampu bertahan sampai di generasi kedua atau ketiga, kemudian tidak dapat berkembang lebih jauh atau bahkan ditutup. Maka dari itu dibutuhkan suatu proses suksesi agar perusahaan keluarga tidak menemui akhir yang buruk. Dalam proses suksesi inilah, komunikasi memiliki peran yang krusial. Salah satu perusahaan keluarga yang telah berhasil melakukan suksesi dengan memaksimalkan komunikasi adalah PT Catur Putra Harmonis. Perusahaan keluarga yang berbasis di Makassar ini tidak hanya berhasil mempertahankan bisnisnya lintas generasi, namun juga mampu mengembangkan bisnis tersebut menjadi lebih luas. Komunikasi memiliki peranan dalam berbagai tahapan suksesi antara lain pembekalan pengetahuan akan perusahaan, pelatihan, uji coba kerja, pertemuan dengan stakeholder, dan pertanggungjawaban kinerja. Komunikasi lintas generasi menjadi kunci utama agar proses suksesi dapat berjalan dengan baik dan lancar.
\end{abstract}

Kata Kunci: perusahaan keluarga, suksesi dan komunikasi

\begin{abstract}
Indonesia is one of the countries whose economies are influenced by family businesses. A study states that 25\% of Indonesia's Gross Domestic Product (GDP) is affected by family businesses. The high influence and role of family business in Indonesia makes the sustainability and growth of family business very important to be considered carefully. But the family company has a unique problem, that is company succession. Often the family business can only survive until the second or third generation, then can not develop further or even closed. Therefore a succession process is needed so that the family company does not have a bad ending. In this succession process, communication has a crucial role. One of the family companies that has managed in making succession by maximizing communication is PT Catur Putra Harmonis. The Makassar-based family company has not only succeeded in maintaining its business across generations, but has also been able to expand the business more broadly. Communication has a role in various stages of succession including the provision of knowledge about the company, training, work trials, meetings with stakeholders, and performance accountability. Cross-generation communication becomes the main key so that the succession process can run well and smoothly.
\end{abstract}

Keyword: Family Business, Sucsesion, Communication 


\section{PENDAHULUAN}

\section{A. Latar Belakang}

Perusahaan keluarga (family business) merupakan salah satu penyokong penting dalam meningkatkan roda perekonomian suatu negara, sehingga perusahaan keluarga dan roda perekonomian merupakan dua hal yang tidak dapat terpisahkan dan saling terkait satu sama lain (Remiasa \& Wijaya, 2014). Perusahaan keluarga merupakan model perusahaan yang terbilang cukup besar dan mendulang kesuksesan di seluruh dunia. Hal tersebut dikarenakan adanya struktur organisasi dan dikelola serta dijalankan oleh anggota keluarga yang biasanya memegang posisi utama di dalam hirarki organisasi. Akan tetapi, pembagian atas kendali perusahaan sangat beragam antara satu perusahaan keluarga dengan yang lainnya. Namun, sangat memungkinkan untuk dapat melakukan identifikasi pola tertentu atas kendali divisi yang didasarkan pada dua faktor penting, yakni struktur organisasi yang berarti apakah posisi utama dikendalikan oleh satu, beberapa, atau banyak orang di dalam perusahaan dan suksesi dalam perusahaan keluarga dari satu tahap ke tahap lainnya yang didasari atas beberapa faktor (Hania, 2012).

Menurut Poza (2010), terdapat sekitar 80\% sampai 95\% perusahaan di Amerika Serikat dan Amerika Latin serta lebih dari $80 \%$ perusahaan di benua Eropa dan benua Asia merupakan perusahaan yang dimiliki oleh keluarga dan perusahaan yang dijalankan oleh keluarga. Lebih mengerucut lagi, pada benua Asia khususnya wilayah Asia Tenggara, 60 persen perusahaan yang berstatus sebagai perusahaan terbuka (tbk.) adalah merupakan perusahaan keluarga (Price Waterhouse Cooper, 2014). Indonesia, salah satu negara yang terdapat di wilayah Asia Tenggara, merupakan salah satu negara yang masuk di dalam daftar 20 negara dengan perekonomian terbesar di dunia dan 5 besar negara dengan perekonomian terbesar di Asia (Saragih, 2018), berpotensi akan menjadi kekuatan ekonomi terbesar ke-4 di dunia pada tahun 2050 setelah Republik Rakyat Tiongkok (China), Amerika Serikat, dan India (Pratama, 2018). Berkaca dari hal tersebut, sebuah riset menyatakan bahwa lebih dari 95 persen perusahaan yang berada di Indonesia dimiliki oleh keluarga dan hadirnya perusahaan keluarga di Indonesia memiliki pengaruh sekitar 25 persen terhadap Produk Domestik Bruto (PDB) Indonesia (Price Waterhouse Cooper, 2014). Tingginya pengaruh serta peranan perusahaan keluarga di Indonesia membuat keberlangsungan dan pertumbuhan perusahaan keluarga menjadi sangat penting untuk diperhatikan dengan saksama.

Berdasarkan riset yang dilakukan oleh salah satu perusahaan auditor terbesar di dunia yakni Price Waterhouse Cooper (PwC) pada tahun 2014, profil perusahaan keluarga di Indonesia dapat diwariskan hingga generasi ketiga dan mayoritas perusahaan keluarga dijalankan oleh generasi kedua seperti pada gambar berikut: 
Gambar 1. Perpindahan Generasi Suksesi dalam Perusahaan Keluarga

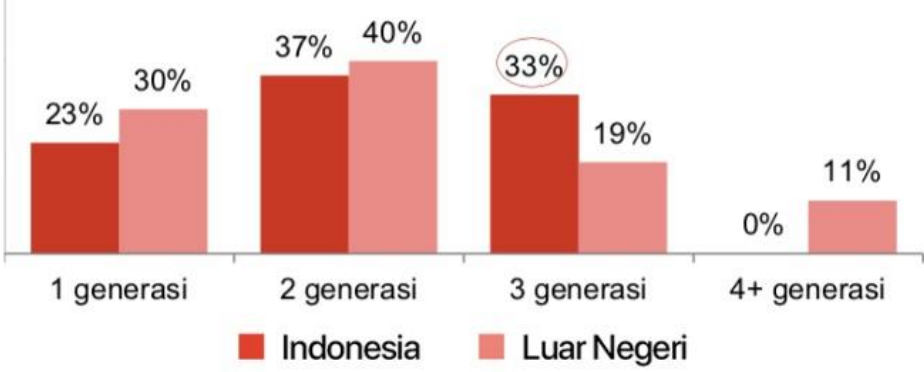

Sumber : Price Waterhouse Cooper Indonesia, 2014

Perkembangan atas perusahaan keluarga tentunya tidak terlepas dari pengaruh suksesi kepemimpinan yang diterapkan di setiap pimpinan dalam setiap generasi. Suksesi kepemimpinan memiliki pengaruh yang cukup signifikan terhadap keberlanjutan perusahaan keluarga. Potensi adanya konflik yang terjadi pada suksesi kepemimpinan dalam perusahaan keluarga adalah konflik nilai yang terjadi antara pendiri yang masih berperan sebagai motor penggerak perusahaan dan anggota keluarga yang terlibat di dalam perusahaan. Mengingat generasi baru cenderung mempunyai pandangan yang berbeda karena umumnya jenjang pendidikan yang ditempuhnya lebih tinggi apabila dibandingkan dengan generasi sebelumnya (Halim, 2013). Suksesi merupakan isu yang sangat krusial, terutama ketika kendali perusahaan sudah mulai bergerak ke arah generasi kedua, generasi ketiga, dan seterusnya. Isu-isu yang biasanya terjadi dalam suksesi, antara lain adalah rencana suksesi yang tidak jelas serta konflik antara caloncalon pengganti. Kata kunci dalam suksesi adalah kapan dan kepada siapa perusahaan akan diwariskan, serta bagaimana komunikasi yang berlangsung didalamnya. Dengan tujuan agar konflik tidak terjadi dalam perusahaan keluarga, perlu dilakukan perencanaan yang matang atas suksesi kepemimpinan. Perencanaan suksesi tersebut juga ditujukan agar tidak terjadi perebutan jabatan dan hak dalam perusahaan keluarga sehingga keluarga juga tetap tentram dan harmonis (Riady, 2017).

Salah satu perusahaan keluarga yang mampu bertahan dalam tantangan ini adalah PT Catur Putraharmonis yang merupakan perusahaan yang bergerak dalam lintas bidang, seperti bengkel otomotif, distributor produk otomotif, serta perhotelan yang didirikan pada tahun 1972 di Makassar, Sulawesi Selatan. PT Catur Putraharmonis telah sukses dalam melaksanakan suksesi kepemimpinan dari generasi pertama ke generasi kedua, serta telah sukses dalam mengembangkan usahanya dalam bentuk ekspansi ke dalam bidang lainnya, seperti perhotelan, yang bukan merupakan bidang usaha utama dari PT Catur Putraharmonis yakni bengkel otomotif dan distributor produk otomotif selama 10 tahun terakhir. Berdasarkan latar belakang masalah diatas, maka dapat ditarik sebuah rumusan masalah yaitu, Bagaimana peran komunikasi dalam proses suksesi yang dilakukan oleh pelaku perusahaan keluarga PT Catur Putra Harmonis? Tujuan dari penelitian ini adalah untuk mengetahui peranan komunikasi yang terjadi selama proses suksesi yang dilakukan dilakukan oleh PT Catur Putraharmonis dari generasi pertama 
kepada generasi kedua. Penelitian ini diharapkan bermanfaat baik secara teoritis untuk menambah kajian pada bidang komunikasi yang diterapkan pada bisnis keluarga, maupun secara praktis untuk memberikan masukan kepada para pelaku bisnis keluarga mengenai pentingkan komunikasi dalam proses suksesi.

\section{B. TinjauanTeoritis}

\section{Perusahaan Keluarga}

Perusahaan dapat dikatakan sebagai perusahaan keluarga jika kendali kepemimpinan, keikutsertaan secara manajerial, dan nilai yang dipeluk oleh pemilik perusahaan atau pimpinan perusahaan dan satu atau lebih anggota keluarga memiliki dampak secara nyata terhadap perusahaan (Poza \& Daugherty, 2014). Pengertian lainnya mengenai perusahaan keluarga menurut Chrisman et al (2009) adalah perusahaan yang disusun dan/atau dijalankan pada bentuk dasar, secara terus menerus dan memungkinkan lintas generasi, dan memiliki visi yang sama yang dapat diterapkan oleh seluruh anggota keluarga.

Terdapat dua macam perusahaan keluarga, yakni: 1) Family Owned Enterprise (FOE), yakni perusahaan yang dimiliki oleh keluarga yang pengelolaannya dilaksanakan oleh pihak luar selain keluarga dan peran keluarga hanya sebatas pemilik dan tidak terlibat dalam kegiatan operasional secara langsung, 2) Family Business Enterprise (FBE), yaitu perusahaan yang dimiliki serta dikelola langsung oleh pendiri dan keluarganya. Ciri perusahaan jenis ini adalah posisi-posisi inti dalam perusahaan yang dipegang oleh anggota keluarga (Susanto \& Susanto, 2013).

\section{Suksesi Kepemimpinan}

Ward (2011) mengartikan perusahaan keluarga sebagai organisasi yang akan dilanjutkan oleh generasi selanjutnya untuk dikelola dan dikendalikan. Generasi selanjutnya pada perusahaan keluarga kerap kali disebut dengan istilah pengganti, suksesor, pewaris ataupun penerus. Suksesi merupakan sebuah "cobaan" utama dan tertinggi pada sebuah perusahaan keluarga. Ketika status perusahaan telah berubah dari usaha secara individual menjadi sebuah perusahaan keluarga, keberlanjutan dan perkembangannya akan menjadi perhatian sesama anggota keluarga.

Suksesi dalam sebuah perusahaan keluarga tidak hanya sekedar suatu hal, tidak hanya sekedar suatu peristiwa yang terjadi ketika pemimpin lama memutuskan untuk pensiun dan menyerahkan kepemimpinan perusahaan kepada pemimpin baru, tetapi merupakan sebuah proses yang sejalan dengan berjalannya waktu. Dimulai pada sedini mungkin dalam kehidupan sebuah keluarga dan terus dilanjutkan hingga generasi penerusnya telah mencapai kedewasaan secara usia dan/atau kehidupannya. Suksesi yang baik membutuhkan waktu yang cukup untuk melalui semua proses itu (Tjiang \& Mustamu, 2014).

Prosesnya, tidak selalu rasional, dapat direncanakan dan berjalan sesuai dengan rencana. Hal ini dikarenakan adanya karakteristik dan kondisi perusahaan serta kondisi keluarga yang tentu saja berbeda satu sama lain. Proses ini dapat dijalankan dengan rumit atau menjadi 
sederhana bagi beberapa perusahaan keluarga, namun jika tidak mengerahkan usaha apapun yang terkait dengan suksesi, perusahaan keluarga seringkali berakhir dengan kehancuran (Leach \& Pedder, 2011).

Mengingat bahwa begitu pentingnya proses suksesi, maka model suksesi yang sesuai dengan kondisi dan kebutuhan diperlukan masing-masing perusahaan keluarga. Menurut Leach \& Pedder (2011), model suksesi diharapkan dapat menjawab beberapa pertanyaan seperti :

a. Kapan waktu yang tepat dalam melaksanakan suksesi.

b. Bagaimana proses dan tahapan suksesi dapat berlangsung.

c. Apa saja yang perlu disiapkan dalam proses tersebut.

d. Siapa saja yang harus terlibat pada saat perencanaan suksesi berlangsung dan diimplementasikan.

e. Bagaimana komposisi saham yang dibagi di antara anggota keluarga.

Poza (2010) menyatakan bahwa terdapat beberapa ciri-ciri karakter seorang suksesor yang berhasil :

a. Mereka sangat memahami perusahaan dengan baik; idealnya, mereka suka atau bahkan mencintainya.

b. Memiliki pemahaman diri sendiri yang baik, baik kelebihan dan kelemahannya, disebabkan memiliki pendidikan dan pengalaman yang memadai.

c. Mereka diarahkan dengan penuh tanggung jawab oleh berbagai pihak di dalam perusahaan, termasuk generasi sebelumnya.

d. Kebutuhan stratejik bisnis sesuai dengan kemampuan dan keahlian yang dimiliki.

Maka dari itu, untuk mendapatkan proses suksesi kepemimpinan yang seefektif mungkin, generasi berikutnya perlu mengembangkan hubungan yang harmonis antara kinerja perusahaan masa lalu hingga kini. Hal ini berguna untuk mencegah kesalahan yang pernah terjadi sebelumnya dan mengantisipasi hal tersebut tidak akan terulang lagi (Tjiang \& Mustamu, 2014).

\section{Komunikasi}

Komunikasi merupakan bagian yang tidak terpisahkan dalam kehidupan. Ada berbagai definisi dari komunikasi berdasarkan studi-studi yang dilakukan oleh para ahli diantaranya sebuah proses pengiriman stimulus atau rangsangan dengan tujuan merubah perilaku orang lain, proses mengolah dan mengirimkan simbol-simbol untuk membentuk makna atau respons dalam diri komunikan yang mana hal tersebut sesuai dengan tujuan komunikator, dan proses pertukaran informasi yang dilaksanakan dua orang atau lebih agar terjalin suatu pengertian yang mendalam (Teguh, 2015). Komunikasi merupakan suatu proses yang dinamis dan berkesinambungan, maka dari itu tidak pernah dapat diketahui kapan proses tersebut dimulai atau berakhir. Hal-hal yang 
terjadi sebelum seseorang berbicara dapat mempengaruhi interaksinya dengan orang lain disekitarnya. Komunikasi adalah proses yang selalu berjalan dan berubah, sehingga merupakan suatu proses yang kompleks dan memiliki elemen-elemen yang tidak terpisahkan (Teguh, 2016). Elemen-elemen komunikasi tersebut dapat dijabarkan sebagai berikut (Lestari \& Yunadi, 2018):

a. Who, merupakan komunikator yang menjadi sumber pengiriman pesan

b. What, merupakan isi dari pesan itu sendiri

c. Channel, merupakan berbagai saluran atau media yang dipakai untuk mentransmisikan pesan

d. Whom, merupakan komunikan yang menerima pesan

e. Effect, meupakan dampak yang terjadi akibat proses komunikasi

Dalam suksesi perusahaan keluarga terdapat beberapa konteks komunikasi yang terjadi. Salah satunya yang krusial adalah komunikasi interpersonal. Komunikasi interpersonal dapat terjadi secara diadik maupun triadik. Komunikasi interpersonal yang berbentuk diadik terjadi diantara dua orang, sedangkan yang berbentuk triadik terjadi diantara tiga orang. Kekhasan komunikasi interpersonal yang menjadi krusial bagi suksesi perusahaan keluarga adalah adanya hubungan antar pribadi. Dalam komunikasi interpersonal yang melibatkan hubungan pribadi ini, para pelaku komunikasi mengungkapkan informasi satu sama lain sekaligus berusaha memenuhi kebutuhan pribadi satu sama lain. Kedekatan antar pribadi juga akan mempengaruhi komunikasi interpersonal, dimana jika para pelaku komunikasi memiliki hubungan yang makin dekat dan akrab maka batasan-batasan dalam komunikasi juga menjadi lebih kecil (Sartika, 2019).

\section{METODE}

Dalam penelitian ini digunakan metode penelitian kualitatif deskriptif. Penelitian deskriptif menurut Sugiyono (2010) merupakan metode penelitian yang digunakan untuk memberi gambaran atau menganalisa mengenai suatu hasil penelitian, akan tetapi tidak digunakan untuk menarik kesimpulan yang lebih luas. Berdasarkan definisi tersebut, dapat dikatakan bahwa penelitian yang bersifat deskriptif merupakan suatu metode penelitian yang didesain untuk membuat deskripsi mengenai suatu situasi atau kejadian yang ada. Penelitian ini dimaksudkan untuk menggambarkan keadaan yang sebenarnya berdasarkan fakta atau data yang ada, kemudian data yang sudah ada diolah, dianalisis, dan diproses lebih lanjut, sehingga pada akhirnya akan menghasilkan suatu kesimpulan mengenai keadaan yang diteliti. Hasil yang ingin didapat dalam penelitian ini adalah mengeksplor peranan komunikasi dalam proses suksesi kepemimpinan yang dilakukan oleh PT Catur Putraharmonis.

Dalam penelitian ini, informan penelitian ditentukan dengan menggunakan teknik purposive yang berarti penentuan kelompok peserta yang menjadi informan berdasarkan kriteria terpilih yang memiliki kaitan yang erat dengan masalah penelitian yang ingin diteliti (Bungin, 2014). Pemilihan informan yang dapat mendukung penelitian ini merupakan informan yang menguasai permasalahan, mempunyai data, dan bersedia untuk memberikan informasi secara 
lengkap dan akurat. Berdasarkan hal tersebut, maka kriteria informan dalam penelitian ini adalah pemilik perusahaan keluarga PT Catur Putraharmonis yang telah menjalankan perusahaan selama 30 tahun terakhir sebagai generasi senior, suksesor perusahaan keluarga PT Catur Putraharmonis yang telah terlibat secara langsung di perusahaan selama minimal 10 tahun terakhir sebagai generasi penerus, serta pakar akademisi dalam bidang perusahaan keluarga.

Dalam melaksanakan penelitian ini, metode pengumpulan data yang digunakan adalah wawancara semi terstruktur yang di mana jenis wawancara ini termasuk dalam kategori in-depth interview dan pelaksanaan wawancara ini lebih bebas apabila dibandingkan dengan wawancara terstruktur (Sugiyono, 2015). In-depth interview merupakan salah satu teknik pengumpulan data secara kualitatif, di mana wawancara dilakukan antara seorang responden (narasumber) dengan pewawancara yang terampil, yang ditandai dengan penggalian akan informasi secara mendalam dan menggunakan pertanyaan yang bersifat terbuka (Iskandar, 2009). Sedangkan tahapan untuk analisis data yang dilakukan adalah (Afrizal, 2015):

a. Reduksi data

Reduksi data merupakan kegiatan pemilihan data penting dan tidak penting dari data yang telah terkumpul. Reduksi data dilakukan dengan cara merangkum dan memilah hal-hal pokok, memfokuskan hal-hal yang penting, dan mencari pola dan tema untuk menarik kesimpulan sementara.

b. Penyajian data

Tahap penyajian data merupakan tahap di mana temuan penelitian disajikan berupa kategori atau pengelompokan. Dalam menyajikan hasil penelitian, dianjurkan untuk menggunakan tabel, grafik, matriks atau diagram, dan lain sebagainya agar lebih mudah dipahami. Metode yang digunakan untuk menyajikan data berupa metode coding (pengkodean). Pengkodean menurut McMillan \& Schumacher (2010) merupakan proses membagi data ke dalam bagian-bagian klasifikasi tertentu.

\section{c. Penarikan kesimpulan atau verifikasi}

Penarikan kesimpulan atau verifikasi merupakan suatu tahap di mana kesimpulan ditarik dari data-data yang telah ditemukan.

Dalam penelitian ini, teknik yang digunakan untuk validitas adalah teknik triangulasi untuk menguji kebenaran datanya. Teknik triangulasi adalah penggunaan dua atau lebih sumber untuk mendapatkan gambaran secara menyeluruh tentang suatu fenomena yang hendak diteliti (Herdiansyah, 2012). Tipe triangulasi yang digunakan dalam penelitian ini adalah triangulasi sumber. Triangulasi sumber untuk menguji kredibilitas data dapat dilaksanakan dengan mengecek data yang telah diperoleh melalui berbagai sumber (Sugiyono, 2014). Triangulasi sumber digunakan oleh peneliti untuk mengecek data yang telah diperoleh dari generasi senior PT Catur Putraharmonis, generasi penerus PT Catur Putraharmonis, serta pakar dalam bidang perusahaan keluarga (family business). Sedangkan uji reliabilitas dalam penelitian ini 
menggunakan teknik dependabilitas. Dilakukan dengan cara penelusuran selama proses penelitian dengan melihat konsistensi jawaban yang didapat dari narasumber selama proses pengumpulan data. Teknik dependabilitas berdasarkan pada asumsi keterulangan dan replikabilitas (Emzir, 2012).

\section{HASIL}

Penelitian ini dilakukan pada perusahaan keluarga PT Catur Putraharmonis, yang bergerak dalam industri jasa (bengkel dan perhotelan) serta distributor produk otomotif yang telah berdiri sejak tahun 1978 di Kota Makassar (d/h Ujung Pandang), Sulawesi Selatan. PT Catur Putraharmonis merupakan distributor resmi sejumlah produk otomotif seperti Dunlop, Accelera-Forceum-Epco, GS-Incoe-Aspira, Mobil-Esso, Denso, Aeolus, Michelin, Hankook, dan Denso untuk wilayah Sulawesi dan Indonesia Timur. PT Catur Putraharmonis memiliki satu kantor pusat (Kota Makassar) dan dua kantor cabang (Kota Palu dan Kota Kendari). Selain menjadi distributor resmi, PT Catur Putraharmonis juga memiliki lima bengkel yang tersebar di beberapa wilayah di Kota Makassar dengan brand Mahaputra. Berbagai macam produk dijual oleh Mahaputra seperti ban mobil, aki, oli, filter udara, filter oli, filter AC, kaca film, dan produk-produk lainnya yang berhubungan dengan produk otomotif. Mahaputra juga di setiap bengkelnya menyediakan jasa cuci mobil, spooring, balancing, ganti aki, ganti ban, ganti oli, pengisian nitrogen, dan sebagainya. PT Catur Putraharmonis sampai dengan saat ini sudah dijalankan hingga generasi kedua dengan suksesornya yakni Ronald Rustan dan Rocky Rustan, anak pertama dan kedua dari Amiruddin Rustan. Suksesi kepemimpinan di PT Catur Putraharmonis telah direncanakan pada tahun 2004 dan diberikan suksesi kepada generasi penerus pada tahun 2008, saat suksesor telah menyelesaikan pendidikan strata satu. Pada tahun 2016, PT Catur Putraharmonis melaksanakan perluasan usaha (ekspansi) ke bidang yang berbeda dari bidang usaha utama, yakni perhotelan. PT Catur Putraharmonis mendirikan MaxOne Hotel \& Resort Makassar yang terletak di Jalan Taman Makam Pahlawan nomor 2 - 5, Kota Makassar. Hotel berbintang 3 plus ini merupakan hotel pertama di Makassar yang menawarkan konsep resort di tengah kota dengan sejumlah fasilitas penunjang.

Berdasarkan Susanto dan Susanto (2013), perusahaan keluarga sejatinya memiliki beberapa karakteristik yang membedakan dengan perusahaan pada umumnya. Pertama, lingkungan pembelajaran yang saling berbagi. Hal tersebut dapat dilihat melalui pembelajaran serta pengetahuan generasi penerus PT Catur Putraharmonis mengenai perusahaan yang didapatkannya sejak generasi penerus berusia muda, sehingga nilai-nilai serta visi misi perusahaan sudah dikenal sebelum generasi penerus benar-benar ikut terlibat di dalam perusahaan keluarga. Disini komunikasi interpersonal memiliki peran, dimana orang tua menanamkan visi misi perusahaan bahkan dalam percakapan sehari-hari. Visi misi perusahaan dijabarkan menjadi nilai-nilai yang disampaikan oleh orang tua kepada anak, sehingga tertanam dalam benak dan pikiran mereka. Hal ini tentunya menjadi frame of reference dan field of 
experience yang dibawa oleh generasi penerus. Kedua, keterlibatan anggota keluarga. Sejak dini, Ronald Rustan maupun Rocky Rustan sudah terbiasa untuk 'dimagangkan' oleh orang tuanya untuk ikut serta dalam perusahaan, baik saat pulang sekolah hingga saat liburan perkuliahan. Sehingga, rasa komitmen terhadap perusahaan keluarga menjadi tinggi ketika generasi penerus mulai terlibat karena keinginan orang tua agar perusahaan dapat lebih berkembang lagi serta sebagai rasa 'balas budi' atas kerja keras orang tua hingga membuat perusahaan dapat berkembang sampai dengan dewasa ini. Disini komunikasi interpersonal terjadi bukan saja dari orang tua kepada penerusnya, namun para penerus juga menjalin komunikasi dengan para karyawan yang terlibat di perusahaan. Hal ini membangun kedekatan antara penerus dengan para stakeholder yang terlibat di perusahaan, sehingga ketika proses suksesi terjadi maka para stakeholder sudah tidak asing dengan suksesor. Hal ini tentunya membantu dalam mengurangi batasan-batasan yang dapat menghalangi kerjasama antara para suksesor dengan stakeholder. Ketiga, tingginya saling keterandalan. Saling diandalkan erat kaitannya dengan rasa percaya. Saling percaya ini dipupuk melalui komunikasi yang intens antara anggota keluarga. Kesediaan untuk saling terbuka dan mendengarkan antara orang tua dan anak-anak, menjadi landasan dari kepercayaan mereka satu sama lain. Ronald Rustan maupun Rocky Rustan memang diberikan kepercayaan terhadap pekerjaan yang dilakukannya. Akan tetapi, kepercayaan diberikan secara penuh di bidang di mana generasi penerus ahli di dalamnya. Serta, rasa percaya yang diberikan harus diikuti dengan adanya tanggung jawab atas apa yang telah dikerjakannya.

Untuk menjaga kelangsungan perusahaan keluarga, maka generasi senior umumnya melakukan proses suksesi, yakni penyerahan wewenang dan kekuasaan kepada generasi penerus. Menurut Remiasa dan Wijaya (2014) dalam penelitiannya mengemukakan bahwa suksesi merupakan sebuah proses pengalihan kekuasaan serta kepemimpinan yang dilaksanakan dengan beberapa langkah untuk memastikan keberlanjutan perusahaan dari generasi ke generasi. Berdasarkan hasil wawancara, dapat disimpulkan bahwa suksesi kepemimpinan berlangsung dengan adanya tahapan berkesinambungan, tidak secara langsung dipindahtangankan dari generasi senior. Menurut informan Ronald Rustan dan Rocky Rustan sebagai generasi penerus PT Catur Putraharmonis, proses suksesi yang telah dijalani keduanya berlangsung sejak kedua informan berusia muda. Dimulai dari membantu di dalam perusahaan baik saat pulang sekolah maupun saat liburan kuliah, kemudian memahami pengetahuan dan diberikan 'pelatihan' baik dari orang tua maupun karyawan yang telah berpengalaman, setelah itu mulai ikut terlibat di dalam pertemuan-pertemuan yang berkaitan dengan perusahaan. Dalam tahapan ini, komunikasi memegang peranan krusial dimana pengetahuan yang disalurkan membutuhkan proses komunikasi agar dapat ditangkap dengan baik. Komunikator yang membagikan pengetahuan juga dilakukan secara selektif, dimana selain orang tua yang adalah pemilik, para suksesor mendapatkan pengetahuan langsung dari karyawan-karyawan yang ahli dibidangnya masingmasing. Pemilihan komunkator ini dilakukan agar para suksesor mendapatkan ilmu yang benar, sehingga dapat menjalankan perusahaan pada masanya. Kemudian pertemuan-pertemuan yang dilakukan juga melibatkan komunikasi pada prosesnya. Awalnya para suksesor hanya diminta 
untuk menjadi pendengar dalam pertemuan-pertemuan sambil diperkenalkan. Setelah lebih memahami bagaimana proses yang berlangsung dalam perusahaan, maka para suksesor mulai diberi kesempatan untuk berkomunikasi dalam pertemuan-pertemuan, misalnya mendiskusikan penyediaan barang dengan supplier. Pada tahap berikutnya, generasi penerus mulai diberikan kepercayaan untuk melaksanakan pekerjaan di bidang tertentu, seperti Ronald Rustan pada bidang back office atau IT dan Rocky Rustan pada bidang pemasaran. Tentunya kepercayaan tersebut diiringi dengan adanya tanggung jawab serta diskusi secara rutin dengan orang tua sebagai pendiri dan pemilik perusahaan. Disinilah komunikasi memiliki peranan, komunikasi rutin untuk menunjukkan hasil kerja dan meminta masukan dan saran untuk pekerjaan yang akan dilakukan membantu para suksesor untuk memahami hal-hal yang sudah baik dan masih perlu ditingkatkan. Kontribusi generasi penerus terhadap perusahaan terus bertambah secara bertahap. Proses suksesi dari perusahaan keluarga PT Catur Putraharmonis telah sampai pada Ronald Rustan dan Rocky Rustan sebagai generasi penerus diberi tanggung jawab untuk mengelola keseluruhan bengkel Mahaputra sesuai dengan keahliannya masing-masing. Hal tersebut didukung di dalam jurnal penelitian Bigliardi dan Dormio (2009) yang menyatakan bahwa suksesi kepemimpinan merupakan sebuah proses jangka panjang dan bertahun-tahun, yang harus dilaksanakan sedini mungkin. Serta, suksesi kepemimpinan dilaksanakan melalui beberapa fase yang akan meningkat sejalan dengan waktu.

Leach dan Pedder (2011) mengemukakan bahwa model suksesi yang terjadi di dalam perusahaan keluarga dilaksanakan atas beberapa kriteria. Berdasarkan pada hasil wawancara, PT Catur Putraharmonis melalui Amiruddin Rustan selaku pendiri dan pemilik perusahaan telah melaksanakan suksesi sejak tahun 2008, di mana Ronald Rustan dan Rocky Rustan sebagai generasi penerus telah menyelesaikan perkuliahan. Akan tetapi, perencanaan akan suksesi kepemimpinan telah dipersiapkan oleh generasi senior sejak tahun 2004. Proses serta tahapan suksesi berlangsung mulai saat Ronald Rustan dan Rocky Rustan ikut membantu di dalam perusahaan baik saat pulang sekolah maupun saat liburan kuliah. Kemudian, kedua generasi penerus tersebut diberikan pembekalan pengetahuan, pelatihan, belajar secara mandiri, terjun langsung bertemu dengan orang-orang, serta diberikan tanggung jawab terhadap pekerjaan yang dikerjakannya. Dalam proses suksesi tersebut, pesan utama yang disampaikan adalah pengetahuan akan perusahaan (nilai-nilai, visi misi, dan sebagainya), memiliki hubungan yang baik dengan semua stakeholder perusahaan, kesiapan generasi penerus untuk belajar mulai dari bawah (mentoring dengan orang tua serta belajar dari karyawan yang sudah berpengalaman), serta kesiapan mental generasi penerus (belajar dari kesalahan serta bertanggung jawab atas pekerjaan yang dilakukan). Pada saat perencanaan suksesi kepemimpinan, Ronald Rustan dan Rocky Rustan berperan sebagai komunikan yang lebih banyak menerima pesan, sedangkan peran orang tua maupun karyawan senior dalam proses ini adalah sebagai komunikator yang memberikan mentoring maupun pendampingan bagi generasi penerus dalam melaksanakan proses suksesi kepemimpinan. 
Komposisi saham yang dibagi diantara anggota keluarga dalam perusahaan keluarga PT Catur Putraharmonis adalah masing-masing anak (generasi penerus) mendapatkan 10\% saham, sedangkan sisanya dikuasai seluruhnya oleh orang tua. Penemuan tersebut didukung dalam jurnal penelitian Haryanto dan Harjanti (2014) yang menyatakan bahwa proses suksesi dilaksanakan melalui beberapa tahap, yakni tahap awal - tahap di mana generasi penerus mulai diperkenalkan dengan perusahaan keluarga, tahap 'pencelupan'-tahap di mana generasi suksesor telah bergabung di dalam perusahaan dan menerima pekerjaan setelah lulus dari pendidikan kuliah, dan tahap tutorial - tahap di mana generasi penerus diberi tanggung jawab yang lebih besar untuk menangani perusahaan. Pembagian saham dilakukan juga dengan mengomunikasikan nilai-nilai yang ingin ditanamkan oleh orang tua kepada generasi penerus. Orang tua mengajarkan kepada anak-anak untuk tetap mengingat jasa orang tua sebagai pendiri, sehingga mereka tidak boleh berintensi untuk mengambil apa yang telah dibangun oleh orang tua. Generasi senior juga mengajarkan generasi penerus agar memiliki daya juang dan mau melakukan ekspansi sehingga muncul kemandirian dalam diri mereka. Disini proses komunikasi interpersonal yang terbuka sangat diperlukan sehingga tidak terjadi kesalahpahaman antara orang tua dan anak karena masalah pembagian harta selalu menjadi topik yang sensitif dalam keluarga. Hal inilah yang dilakukan PT Catur Putra Harmonis sehingga pembagian saham dapat berlangsung dengan baik tanpa adanya pertikaian baik antara orang tua dengan anak maupun antar saudara.

\section{KESIMPULAN}

Berdasarkan hasil analisis dan pembahasan yang telah dilakukan, maka dapat diambil kesimpulan bahwa PT Catur Putraharmonis merupakan perusahaan keluarga dengan tipe Family Business Enterprise (FBE), di mana PT Catur Putra Harmonis dimiliki serta dikelola secara langsung oleh pendiri dan keluarganya. Serta, posisi-posisi inti dalam perusahaan dipegang langsung oleh anggota keluarga. Hal tersebut dapat dilihat dari keterlibatan Amiruddin Rustan sebagai pendiri PT Catur Putraharmonis yang telah mengelola perusahaan selama lebih dari 30 tahun, serta melibatkan anak dari Amiruddin Rustan yakni Ronald Rustan dan Rocky Rustan sebagai generasi penerus PT Catur Putraharmonis yang juga menjabat sebagai direktur. Perusahaan keluarga sejatinya memiliki karakteristik yang dapat membedakan dengan perusahaan lainnya. Tidak terkecuali dengan PT Catur Putraharmonis. Karakteristik tersebut antara lain lingkungan pembelajaran yang saling berbagi-pengetahuan generasi penerus akan perusahaan sudah didapatkan sejak berusia muda, keterlibatan anggota keluarga—Ronald Rustan dan Rocky Rustan sudah 'dimagangkan' di perusahaan sejak muda, serta tingginya saling keterandalan_-generasi penerus diberikan kepercayaan di bidang di mana generasi penerus ahli di dalamnya.

Model proses suksesi kepemimpinan yang terjadi di dalam perusahaan keluarga PT Catur Putraharmonis dimulai sejak tahun 2008, dimana Ronald Rustan dan Rocky Rustan telah 
menyelesaikan pendidikan perkuliahan. Akan tetapi, persiapan suksesi kepemimpinan telah direncanakan sejak tahun 2004. Proses suksesi mulai berlangsung saat Ronald Rustan dan Rocky Rustan ikut membantu dalam perusahaan; kemudian generasi penerus diberikan pembekalan pengetahuan, pelatihan, belajar secara mandiri, bertemu dengan stakeholder, serta diberikan tanggung jawab atas pekerjaan yang dikerjakannya. Yang disiapkan dalam proses suksesi tersebut adalah pengetahuan akan perusahaan, kesiapan generasi penerus untuk belajar, dan kesiapan mental generasi penerus. Yang terlibat dalam proses suksesi kepemimpinan selain generasi penerus, orang tua dan karyawan senior turut terlibat baik sebagai mentor maupun sebagai pendamping. Komposisi saham yang dibagi diantara anggota keluarga adalah $10 \%$ bagi masing-masing anak (generasi penerus) dan sisanya dimiliki penuh oleh orang tua. Dalam proses suksesi tersebut melibatkan komunikasi interpersonal yang intens. Komunikasi interpersonal pertama terjadi antara orang tua dan anak, disini orang tua banyak menanamkan nilai-nilai yang harus dipegang anak dan membagikan pengetahuan dan pengalaman mereka tentang perusahaan. Anak juga menginformasikan kepada orang tua mengenai pengalaman mereka, bisa jadi kendala maupun keberhasilan mereka selama proses suksesi berlangsung. Hal inilah yang merajut kepercayaan dan kedekatan yang baik, sehingga saat pembicaraan mengenai pembagian saham diberikan, anak-anak dapat memahami maksud orang tua dalam pembagian saham. Selain dengan orang tua, para suksesor juga melakukan komunikasi interpersonal dengan para stakeholder, mulai dari mendapatkan informasi dari para karyawan senior, sampai dapat mendiskusikan berbagai hal dengan stakeholder lain seperti pemasok dan konsumen. Sejauh ini proses suksesi dengan komunikasi interpersonal yang intens antar anggota keluarga menunjukkan hasil yang positif dimana tidak ada kesalahpahaman maupun pertengkaran dalam perusahaan. Hal ini diharapkan dapat terus dikembangkan sampai dengan generasi selanjutnya sehingga PT Catur Putra Harmonis dapat terus berkembang. 


\section{DAFTAR PUSTAKA}

Afrizal. (2015). Metode Penelitian Kualitatif: Sebuah Upaya Mendukung Penggunaan Penelitian Kualitatif dalam Berbagai Disiplin Ilmu. Jakarta: PT. Raja Grafindo Persada.

Bigliardi, B., \& Dormio, A. I. (2009). Successful Generational Change in Family Business. Measuring Business Excellence, 13(2), 44-50.

Bungin, B. (2014). Penelitian Kualitatif. Jakarta: Kencana Prenada Media.

Chrisman, J., Chua, J., Sharma, P., \& al, e. (2009). Guiding Family Business Through The Succession Process, A Step-by-step Guide For CPA Advisors. The CPA Journal, 48-51.

Emzir. (2012). Metode Penelitian Kualitatif: Analisis Data. Jakarta: Rajawali Pers.

Halim, Y. (2013). Analisa Suksesi Kepemimpinan pada Perusahaan Keluarga PT. Fajar Artasari di Sidoarjo. Agora, 3(1), 1-15.

Hania, M. F. (2012). Factors Influencing Family Business Succession, Case Study: Gaza Family Businesses. Gaza: The Islamic University of Gaza.

Haryanto, S., \& Harjanti, D. (2014). Analisis Proses Suksesi pada Perusahaan Keluarga Berbudaya Tionghoa (Studi Kasus pada PT X). Agora, 2(2), 1-6.

Herdiansyah, H. (2012). Metode Penelitian Kualitatif: Untuk Ilmu-Ilmu Sosial. Jakarta: Salemba Humanika.

Iskandar. (2009). Metodologi Penelitian Pendidikan dan Sosial (Kuantitatif dan Kualitatif). Jakarta: GP Press.

Kriyantono, R. (2009). Riset Komunikasi . Jakarta: Kencana Prenada Media Group.

Leach, P., \& Pedder, R. (2011). Family Businesses: The Essentials. London: Profile Books.

Lestari, S. S., \& Yunadi, A. (2018). Pola Komunikasi Pelatih Terhadap Atlet Sekolah Sepak Bola (SSB) Kampar Junior. Jurnal Communiverse, 4(1), 1-6.

Maxwell, J. A. (2012). The Importance of Qualitative Research. sagepublications, 655-661.

McMillan, J. H., \& Schumacher, S. (2010). Research in Education: Evidence-Based Inquiry, 7th Edition. London: Pearson.

Poza, E. J. (2010). Family Business: Third Edition. Boston: Cengage Learning.

Poza, E., \& Daugherty, M. (2014). Family Business: Fourth Edition. Boston: Cengage Learning.

Pratama, A. (2018, Mei 9). Indonesia Masuk 5 Besar Ekonomi Terbesar Dunia Tahun 2050. Retrieved from CNBC Indonesia: https://www.cnbcindonesia.com/news/20180509181053-16-14351/indonesia-masuk-5besar-ekonomi-terbesar-dunia-tahun-2050

Price Waterhouse Cooper. (2014, November 1). Survey Bisnis Keluarga 2014. Retrieved from Price Waterhouse Cooper: https://www.pwc.com/id/en/publications/assets/indonesiareport-family-business-survey-2014.pdf

Remiasa, M., \& Wijaya, S. A. (2014). Analisis Proses Suksesi Perusahaan Keluarga: Studi pada PT. Puterasean. Kinerja, 18(2), 141-156.

Riady, N. (2017). Analisis Efektivitas Proses Suksesi Kepemimpinan pada PerusahaanPerusahaan Keluarga Etnis Tionghoa. Agora, 5(3), 1-6. 
Saragih, H. P. (2018, Februari 18). 20 Negara dengan PDB Terbesar di Dunia. Retrieved from CNBC Indonesia: https://www.cnbcindonesia.com/news/20180218140126-16-4654/20negara-dengan-pdb-terbesar-di-dunia

Sartika. (2019). Teknik Aba Sebagai Sarana Komunikasi InterpersonalAntara Ibu Dan Anak Penyandang Autisme di PLA (Pusat Layanan Autis) Riau. Jurnal Communiverse, 4(2), $30-41$.

Sugiyono. (2010). Metode Penelitian Pendidikan Pendekatan Kuantitatif, Kualitatif, dan R\&D. Bandung: Alfabeta.

Sugiyono. (2014). Metode Penelitian Pendidikan (Kuantitatif, Kualitatif, dan R\&D. Bandung: Alfabeta.

Sugiyono. (2015). Metode Penelitian Pendidikan (Kuantitatif, Kualitatif, dan R\&D). Bandung: Alfabeta.

Susanto, A., \& Susanto, P. (2013). The Dragon Network: Inside Stories of the Most Successful Chinese Family Businesses. Singapore: John Wiley \& Sons.

Teguh, M. (2015). Model Komunikasi Kesehatan Pada Masyarakat Pedesaan Indonesia (Studi Pada Sosialisasi Buku Pintar KIA Bagi Calon Pengantin di Kabupaten Trenggalek, Jawa Timur). In Komunikasi dan Isu Publik (pp. 43-56). Yogyakarta: ASPIKOM dan Buku Litera.

Teguh, M. (2016). The Communication Process In "River Clinic" Activity. International Conference oc Communication Science Research (pp. 201-211). Surabaya: Faculty of Communication Science Dr. Soetomo University.

Tjiang, C. G., \& Mustamu, R. H. (2014). Studi Deskriptif Perencanaan Suksesi Kepemimpinan pada Perusahaan Keluarga di Bidang Konstruksi di Sidoarjo. Agora, 2(2), 1-11.

Ward, J. L. (2011). Keeping the Family Business Healthy: How to Plan for Continuing Growth, Profitability, and Family Leadership. Basingstoke: Palgrave Macmillan. 